\title{
Status of Solar Energy Potential, Development and Application in Myanmar
}

\author{
Hla Myo Aung \\ Renewable Energy Research \\ Department, Department of \\ Research and Innovation, \\ Yangon, Myanmar
}

\author{
Zaw Min Naing \\ Department of Research and \\ Innovation, Yangon, Myanmar
}

\author{
Thi Thi Soe \\ Renewable Energy Research \\ Department, Department of \\ Research and Innovation, \\ Yangon, Myanmar
}

\begin{abstract}
Myanmar has abundant of renewable energy resources through the country. Among the renewable energy available, the potential of solar energy is one of the great interests in Myanmar. The government of Myanmar has set a plan to electrify the whole county in 2030. On the other hand, ASEAN has a target that is to increase 23\% of Renewable Energy in ASEAN generation mix by 2025. For the time being, Myanmar has mainly relied on hydropower system for the electricity generation. Due to lack of water in summer season in Myanmar, Solar Energy will be a vital role in Electricity generation because of the high sunshine hours for that time. Therefore, the government of Myanmar is trying to increase the utilization of solar energy for the rural electrification. In this respect, the seventy percent of population are living in rural area where they cannot access the electricity. For the off-grid area, Myanmar has mainly emphasis on solar home system and mini-grid system to be sustainable, affordable and environmental friendly. This paper aims to describe the high potential of solar energy, current situation of solar energy implementations and the important of Renewable Energy of Myanmar respectively. This paper is also intends to know good opportunity for international investors and developers concerning solar energy. This paper presents Hence, The current status, future potentials of solar energy sector and solar energy development in Myanmar are presented in this context. In this paper, also up to date information is provided for the solar energy sector of the country.
\end{abstract}

Keywords: solar energy, renewable energy, rural electrification, off-grid area, mini-grid system, environmental friendly

\section{INTRODUCTION}

Myanmar is Located between the Himalaya in the north and the Andaman Sea to the south, and roughly shaped like a diamond. The landscape of Myanmar is as diverse as it is intriguing. Wedged between China to the east and India to the west. Myanmar also shares borders with Thailand, Laos and Bangladesh. Stretched over 676,578sq km, it is the 40thlargest in South-east Asia, behind Indonesia. The coastline stretches out $2832 \mathrm{~km}$, with the Bay of Bengal on the south-west coast and the Andaman Sea to the south-west coast and the Andaman Sea to the south-east.

Myanmar is the member of ASEAN, located in South East Asia and with a population of more than $51 \mathrm{~m}$ Scattered across 14 states/ regions with 412 townships/sub- townships, Myanmar is the 12th most populous country in Asia and the fifth in South- east Asia, behind Indonesia, the Philippines, Vietnam and Thailand. The three main cities are the business capital of Yangon, with a population of more than $7.3 \mathrm{~m}$; followed by the second business capital of Mandalay, with $1.73 \mathrm{~m}$ people, and the administrative capital of Naypyidaw, which has approximately $1.16 \mathrm{~m}$ inhabitants.[1]

\section{ENERGY SECTOR AND SOLAR POTENTIAL IN MYANMAR}

Overall, Myanmar's total final energy consumption increased between 2000 and 2013 by an average $2.3 \%$ annually, from 11 Mtoe to 14.3 Mtoe. Over this period energy consumption by the industrial has doubled, the consumption by the commercial sector grew three times as much, whereas energy use in transport sector has not increased generally. Residential consumption increased only by $1.3 \%$ annually but, it remains by far the largest consumer of energy due to exclusive use of biomass (fuel wood and charcoal).[2]
The existing electricity capacity and infrastructure can only meet about $50 \%$ of the current electricity demand resulting in regular load shedding and challenges in electricity supply management. In total electricity installed capacity in Myanmar, hydroelectric power $64.37 \%$ and $31.31 \%, 2.4 \%$, $1.83 \%$ and $0.09 \%$ of electricity generation installed by gas, coal, diesel and biomass as shown in Figure 1.[3]

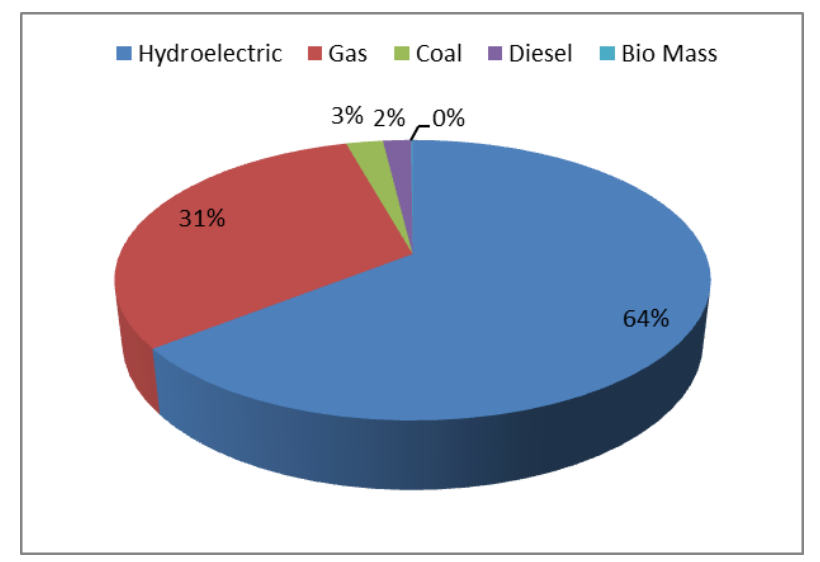

Figure.1 Installed Generation Capacity as in 2016 (June)

POTENTIAL OF SOLAR ENERGY IN MYANMAR: In Myanmar, it enjoys abundant sunshine all year round, especially in the Central Myanmar Dry Zone Area. Potential available solar energy of Myanmar is around 51973.8 $\mathrm{TWh} /$ year in accordance with NEDO surveying data in 2003. On average, daily global solar radiation in Myanmar varies from the value of $15 \mathrm{MJ} / \mathrm{m} 2$-day in the north and the east to $20 \mathrm{MJ} / \mathrm{m} 2$-day in the west as shown in Figure 2. High solar radiation (>20 MJ/m2-day) is observed mostly in the fertile plains including the areas of Magway, Mandalay and Sagaing Regions. In the north, low solar radiation (14 MJ/m2-day) is observed as a result of cloudy skies generated from the cold 
front system. On the other hand, the pattern of low solar radiation (16-18 MJ/m2-day) is also seen in the east and the south regions. This is because of the monsoons, which bring heavy rains and clouds. In contrast, high solar radiation (20$22 \mathrm{MJ} / \mathrm{m} 2$-day) is seen over the areas of Mandalay, Magway and Sagaing Regions.

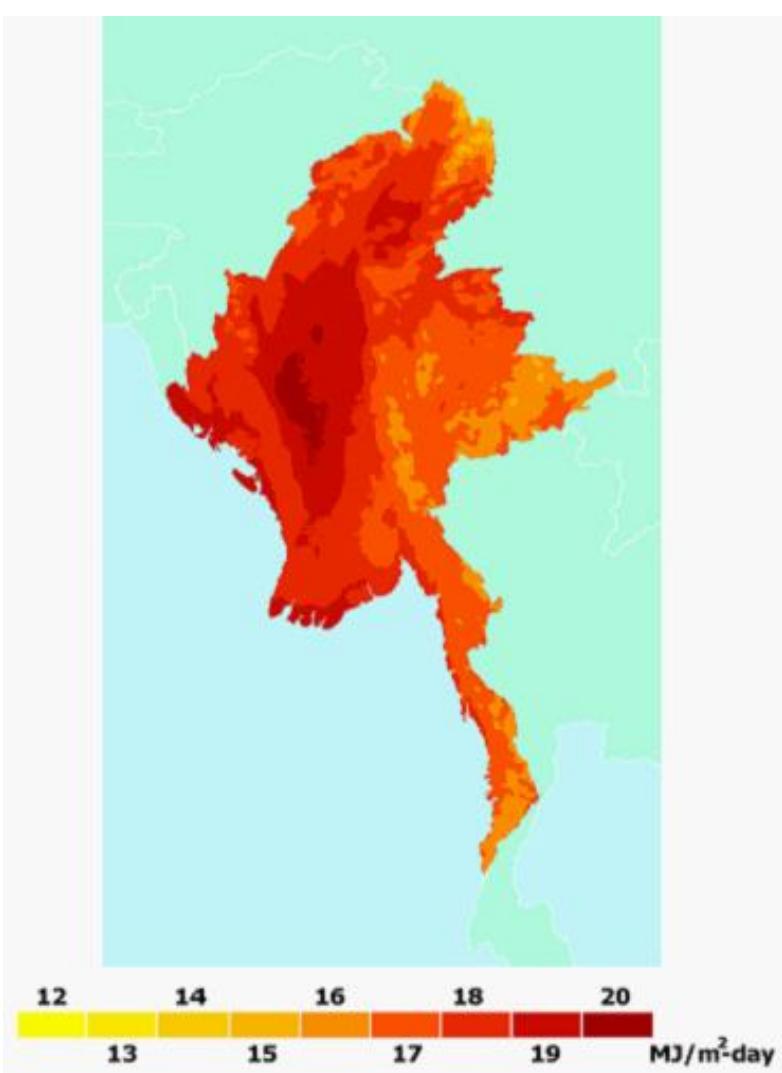

Figure. 2 Yearly average of daily global radiation over Myanmar

The year average solar radiation of Myanmar is found to be 18.3 MJ/m2-day, when averaged over the country. The annual maximum solar irradiation is in February and the minimum in July-August.[4]

\section{RELATED POLICY AND INSTITUTION FRAMEWORK FOR ENERGY SECTOR}

Myanmar lacks a unified policy for promoting the development and use of its renewable energy resources. The government has not yet officially established renewable energy targets. The national grid infrastructure is not reliable to accept the renewable energy generating sources. Electricity Law was legislated by the Union Parliament in Oct, 2004 and formulation of by laws are also ongoing. National Electricity master Plan (final draft II) was prepared by JICA and submitted to Ministry in Aug, 2014. In the National Electricity Master Plan, renewable energy (only solar and wind) share would be $9 \%$ (2000MW) of installed capacity by 2030[5]. Followed by ASEAN target, the component of renewable energy will be increased to $23 \%$ by 2025 in the ASEAN Energy Mix [6]. The Myanmar National Electrification Plan (NEP) aims to electrify $100 \%$ of Myanmar's households by 2030[3]. However, institutional and regulatory framework is still fragmented in renewable energy sector. There are two National plans regarding energy sector in our country. They are National Energy Master Plan has been finalized by the management of National Energy Management Committee (NEMC), under the Ministry of Energy during the previous government.

\subsection{National Energy Master Plan}

The National Energy Master Plan had been accomplished by the assistance of ADB in December 2015. Among these nine policies, renewable energy is;

(i) To implement programs on a wider scale, utilizing renewable energy resources such as wind, solar, hydro, geothermal and bio-energy for the sustainable energy development in Myanmar [2]

By mid-2014, Renewable Energy Research Department under the Department of Research and Innovation (DRI), Ministry of Science and Technology has completely formulated Renewable Energy Policy, Strategy and Roadmap Myanmar (First Draft) which covers the proposed activities in the key sectors and the road map for implementation of the RE Policy.

The first draft was contributed to the concerned Ministries and organization to fill up the existing and implementation plan for future trend of Renewable Energy to meet 27\% target of Renewable Energy development until 2030. In accordance with the comments and suggestions from the concerned Ministries, finally the second draft of RE policy had been completed in January, 2016. In the formulation of RE policy First draft, it has targeted to fulfill the RE final goal of $27 \%$ in total installed capacity, the certain amount from four types of renewable energy sources will be allocated such as hydropower power $1.3 \%$, solar $17.8 \%$ (on grid) $3.7 \%$ (off grid), biomass $1 \%$, bio gasification $0.02 \%$ and bio-fuel $5 \%$ by comparing with existing and demand \& find the way as adder. The draft Renewable Energy Policy is presented to the Parliament for consideration. The focus is on the development of the following:

A. Domestic Energy (improve cooking stove)

B. Thermal Energy (Solar water heating, waste heating utilization plants, training and education of efficient solar thermal uses)

C. Grid Connected Renewable Energy (the most attention and investment of RET are wind, solar and biomass and RET offer a valuable contribution to the national electricity production and to energy security)

D. Off-Grid Renewable Energy (GOM will apply in Off-grid RE delivery models with the advantages of learning from international experience in order to achieve the rural electrification targets)

E. Energy Research (conduct research on improving existing technologies and emerging viable and marketable technologies)

\subsection{National Electrification Plan (NEP)}

The Department of Rural Development (DRD) of the MOAI therefore has embarked on the renewable energy based national electrification program. The main objective of the NEP is to achieve universal access to electricity in Myanmar by 2030. With technical assistance from World Bank Group, the Government developed a National Electrification Plan in 2014 to accomplish this rapid increase through a two-pronged, sector-wide approach: an ambitious extension of the national grid plus off-gird electrification for communities that would otherwise have to wait for years for grid access. NEP aims to 
support from different stakeholders with the implementation program for achieving national access targets as the following:

i. Dense areas require less MV per connection and will be connected first.

ii. Remote communities require more and will be connected later.

iii. Major areas for Pre electrification have higher cost per connections, thus to be connected in the final phases.

The total cost of National Electrification Program is estimated at US $\$ 5.8$ billion (grid and off-grid) till 2030. NEP aims to electrify 7.2 million households and achieve universal access to electricity by 2030 as shown in Figure 3.[3]

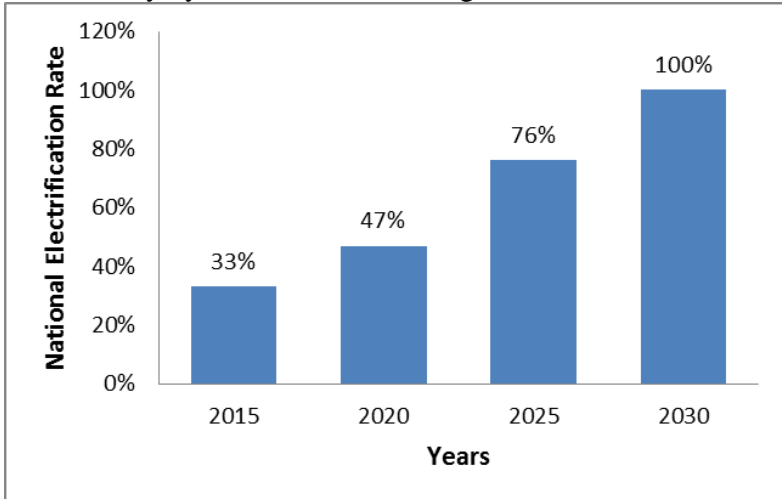

Figure. 3 National Electrification Plan (NEP)

\subsection{Institutional Framework for Energy Sector of Myanmar}

The structure of energy sector in Myanmar is very fragmented and the responsibilities for various aspects of energy development in Myanmar. For the time being, Ministry of Electricity and Energy (MoEE) is responsible for the overall focal point for energy policy, coordination and international cooperation and also the oil and gas sector for developing, operating, and maintaining all large hydropower and coalfired thermal plants; for developing and maintaining the transmission and distribution systems throughout the country, and for operating gas-fired thermal plants and mini hydropower plants. In addition, Ministry of Agriculture and Irrigation (MoAI) is take the lead in the development of biofuels, micro-hydropower (with installed capacity of up to $10 \mathrm{MW}$ ), bioenergy from agricultural residues, and biogas. Ministry of Education (MoE) is one of the energy concerned Ministry that conducts for the research and development of Renewable Energy technologies and promotion of renewable energy sector in Myanmar. And also Ministry of Natural Resource and Environmental Conservation regulates the use of biomass from forest resources for energy purposes and climate change issues. Finally, Ministry of Industry (MoI) is undertaking the formulation of Energy Efficiency and Conservation policy and also leading role on the development and implementation of Energy Efficiency and Consecration sector in Myanmar.

\section{DEVELOPMENT AND APPLICATION OF SOLAR ENERGY IN MYANMAR}

The Government of the Republic of the Union of Myanmar (GoM) has a policy to support to the utilization of renewable energy and private investment in the electricity sector. The draft Power Generation Development Plan (PGDP) proposed by JICA financed electricity sector master plan study sets a target of renewable of solar, wind, biomass and geothermal to be developed by 2,000 MW, which is equivalent to $10 \%$ of the power supply capacity at 2030 as assumed in the draft document. A Memorandum of Understanding was recently signed between MoEE and US investors of a solar PV project to Myanmar. The project consists of two $150 \mathrm{MW}$ facilities, one in Nabuai and the other in Wundwin, both locations in Mandalay Region. The published project cost is $480 \mathrm{~m} \$$, equal to $1,600 \$ / \mathrm{kW}$. The targeted commissioning of the project is in 2016. Also a Thai company has been pursuing a 220 MW solar power plant in Minbu in Magway Region as shown in Figure 4. The cost assumptions made here are 2,100 $\$ / \mathrm{kW}$ for a solar PV plant operating on average at $20 \%$ capacity factor.

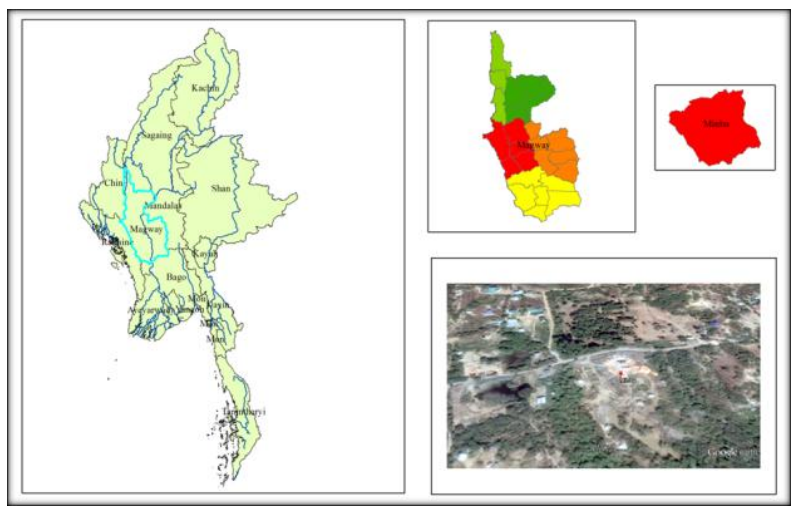

Figure. 4 Project Location (Magway Division, Minbu District, Sagu Township)

Green Earth Power (Myanmar) Co., Ltd (GEP) appointed Shwe Kyun Gyi Construction Co., Ltd (SKG) to start preliminary civil work since July, 2015. They have completed $100 \%$ of site clearing and construction of compacted gravel soil road (access road) at the site. At the moment, they started grading phase one areas, substation areas and office areas. Minbu Solar Power Project is located in Minbu district, Magwe region and the capacity is approximately 220MW (Phase I 50MW, Phase II 50MW, Phase III 50MW and Phase IV 70MW) respectively. On the other hand, Myanmar Electric Power Enterprise (MEPE) completed in the construction the $30 \mathrm{kV}$ of National transmission line by April, 2016. Project land area has about 836 acres wide and lease hold from Government. Myanmar Electric Power Enterprise under the Ministry of Electricity and Energy will be off taker. The electricity tariff will be $0.1275 \mathrm{US} \$ / \mathrm{kWh}$ and the project life is 30 years plan. The project construction time will take totally 48 months (Phase 1 complete in 12 months, Phase II in 24 months, Phase III in 36 months and Phase IV in 48 months).[7]

\subsection{Off-grid Solar Power Generating System for Rural Area}

In recent years, following off-grid solar power generating systems have been rapidly developed in Myanmar.

$\begin{array}{ll}\text { i. } & \text { Solar water pumping system } \\ \text { ii. } & \text { Industry, Telecommunications \& Public service } \\ \text { iii. } & \begin{array}{l}\text { Solar Lighting for streets, gardens and public } \\ \text { transportation stops }\end{array} \\ \text { iv. } & \text { Solar refrigeration system for Health } \\ \text { v. } & \begin{array}{l}\text { Solar Home system for Residential (especially in } \\ \text { lighting for houses) }\end{array}\end{array}$


Solar Home System (SHS) is divided by three categories for off-grid rural electrification in Myanmar. They are small (capacity range $30 \mathrm{~kW})$, medium $(45 \mathrm{~W})$ and large scale $(60 \mathrm{~W})$ respectively in as described in Table 1.[8]

Table 1. solar home system for off-grid rural electrification

\begin{tabular}{|c|c|c|c|}
\hline $\begin{array}{c}\text { Solar Panel } \\
\text { peak wattage } \\
\text { (Wp) }\end{array}$ & 30W & $\mathbf{4 5 W}$ & $\mathbf{6 0 W}$ \\
\hline $\begin{array}{c}\text { Load } \\
\text { consumption }\end{array}$ & $\begin{array}{c}\text { Three LED } \\
\text { lights, } \\
\text { a cell phone }\end{array}$ & $\begin{array}{c}\text { Four LED } \\
\text { lights, } \\
\text { a cell phone } \\
\text { and TV }\end{array}$ & $\begin{array}{c}\text { Five LED } \\
\text { lights, } \\
\text { a cell phone } \\
\text { and TV }\end{array}$ \\
\hline
\end{tabular}

In Myanmar, There are four types of Solar photovoltaic (PV) application in public institution system and implemented by Department of Rural Development (DRD), under the Ministry of Agriculture and Irrigation (MoAI). These are primary, middle and high school, rural health Centre, religious building and street light as shown in Table 2.[8]

Table 2. Application of Solar PV system

\begin{tabular}{|c|c|c|}
\hline Application & $\begin{array}{c}\text { Solar Peak } \\
\text { Power }(\mathbf{W p )}\end{array}$ & Load \\
\hline Primary School & 120 & $\begin{array}{c}\text { 9 LED lights, Tablet } \\
\text { and Cell phone }\end{array}$ \\
\hline Middle School & 375 & $\begin{array}{c}\text { 20 LED lights, } \\
\text { Tablet and Cell } \\
\text { phone }\end{array}$ \\
\hline High School & 475 & $\begin{array}{c}\text { 26 LED lights, } \\
\text { Tablet and Cell } \\
\text { phone }\end{array}$ \\
\hline $\begin{array}{c}\text { Rural Health } \\
\text { Center }\end{array}$ & 180 & $\begin{array}{c}\text { 6 LED lights, Cell } \\
\text { phone and small } \\
\text { appliance }\end{array}$ \\
\hline Religious Building & 120 & 9 LED lights \\
\hline Street light & 70 & 1 LED light \\
\hline
\end{tabular}

\subsection{Research \& Development (R\&D) and Human Resource Development (HRD) for Solar Energy Technology}

DRI under MOE has been involved as the leading department for the formulation of RE policy. Researchers from DRI have been conducting researches in the field of Renewable Energy, particularly biogas, rice rush gasifier, wind turbine, solar and micro hydro power projects. For the solar technology, design models and solutions are contributed for utilization of solar energy to the village people in Myanmar. In addition, training courses on renewable energy technology and application including solar energy technology have been disseminated by DRI starting from 2014.

The Renewable Energy research department under the DRI is doing research for renewable energy technologies (especially Solar, Wind, Hydro, Gasifier and Biogas). Regarding international cooperation, DRI signed in $\mathrm{MoU}$ with Ministry of New and Renewable Energy in India for the cooperation on development of new and renewable energy technologies focusing on solar energy, bio-energy and wind energy in August, 2016. Currently, DRI is trying to be able to sign in MoU with Asia Air Survey (Japan) company for research and development on renewable energy. Moreover, DRI have cooperated with ADB, UNIDO, and GIZ. DRI also co-operate with Renewable Energy Association in Myanmar (REAM), Green Energy Green Growth (GEGG) and Myanmar Engineering Society (MES) to enhance the development of renewable energy sector. The summary Training and Awareness Program on Renewable Energy (Solar, Wind, Hydro, Gasifier and Biogas) has being provided by DRI as shown in Figure 5.

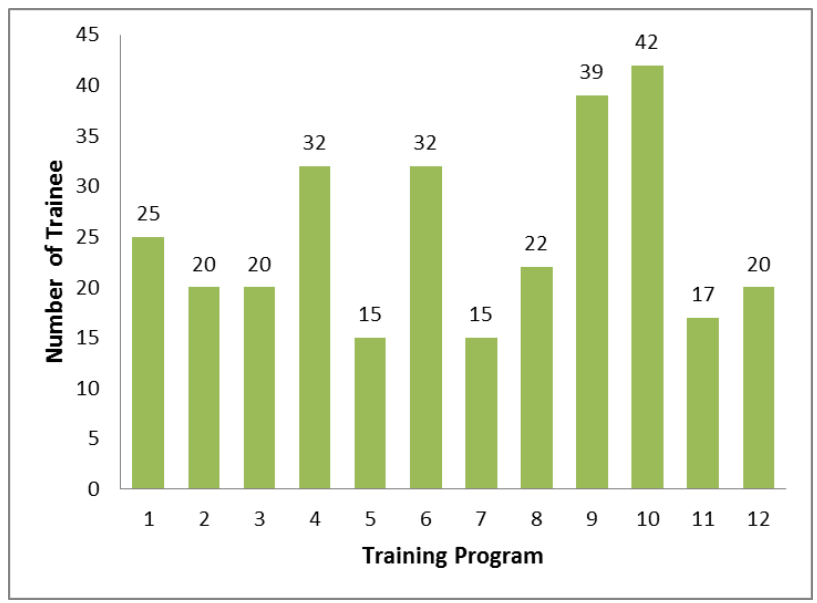

Figure. 5 Training and Awareness Program on RE technologies provided by DRI

\section{RESULT AND DISCUSSION}

For the time being, Government of Myanmar considers to increase the utilization of Renewable Energy to reduce the environmental impact and for increasing of electricity demand. Most of the state and region have become implement the large scale solar power project. For example, the 30MW solar project will be implemented in Maubin Township, Irrewarddy region, Myanmar. The high authorized people consider the wide range of solar power plant application in energy master plan.

There are many challenges in the development of renewable energy sector. Renewable Energy is often considered as nonviable energy solution compared to the subsidized conventional energy generation and also lack of consumer awareness on benefits and opportunities of renewable energy. There is still need for renewable energy development in our country. Moreover, regarding development of solar energy, advanced technologies such as design of solar panels, solar energy conversion, processing technologies, modeling, simulation and engineering of solar plants are important issues in Myanmar.

Above challenges can be effectively overcome through the following recommendation:

i. RE policy, strategy and roadmap need to be finalized to ensure RE contributes significantly to the energy mix and enhance public awareness on benefits \& opportunities of RE

ii. The Government of Myanmar would have in place an appropriate legal and regulatory frame work with enforcement mechanism

iii. It is necessary to strengthen training and capacity building for local technical officers and mini-grid project developers 
iv. Related organizations need to provide transparent information on energy costs, resource availability, subsidies, RE policies, and roadmap to project developers

International support (funding, capacity building, and technology transfer) to help Myanmar implemented RE policy to meet the target of ASEAN renewable energy.

\section{CONCLUSION}

Myanmar has very weak of cooperation and collaboration within and between various concerned ministries,

\section{ACKNOWLEDGMENTS}

Our thanks to the experts who have contributed towards development of the template. The author would like to express special thanks to Dr. Zaw Min Naing, Deputy Director General and Head, Renewable Energy and Electronic Technology Research Center, Department of Research and Innovation, for his effective suggestions and valuable ideas. The author is deeply grateful to Dr. Thi Thi Soe, Deputy Director, Renewable Energy Research Department, Department of Research and Innovation, for his invaluable support, suggestions and sharing experience in the research period.

\section{REFERENCES}

[1] August 2014, ADB report, Renewable Energy Developments and potential in the Greater Mekong Subregion. .

[2] 19 December 2014, MYANMAR ENERGY MASTER PLAN, the Asian Development Bank and the Myanmar Ministry of Energy. development partners, private sectors, institutes, universities and other stakeholders for the progress in RE development. In this paper we studied current status and policy development of renewable energy in Myanmar. In fact, according to discussion the condition of solar energy resource is good potential in Myanmar but requires additional attention for better development of solar energy source.

[3] September 2014, Myanmar National Electrification Program (NEP) Roadmap and Investment Prospectus: Final road map and investment prospectus

[4] September, 2009, Assessment of Solar Energy Potentials for Myanmar, Solar Energy Research Laboratory, Department of Physics, Faculty of Science, Silpakorn University, Thailand.

[5] Forman, G. 2003. An extensive empirical study of feature selection metrics for text classification. J. Mach. Learn. Res. 3 (Mar. 2003), 1289-1305.

[6] Brown, L. D., Hua, H., and Gao, C. 2003. A widget framework for augmented interaction in SCAPE.

[7] Y.T. Yu, M.F. Lau, "A comparison of MC/DC, MUMCUT and several other coverage criteria for logical decisions", Journal of Systems and Software, 2005, in press.

[8] Spector, A. Z. 1989. Achieving application requirements. In Distributed Systems, S. Mullender 